\title{
A CINERARY URN FROM SITE 21 IN OSTRÓW, PRZEMYŚL DISTRICT. A CONTRIBUTION TO STUDIES ON THE MEANING AND ROLE OF ORNAMENTATION OF EARLY ROMAN PERIOD CERAMIC VESSELS IN THE PRZEWORSK CULTURE
}

\begin{abstract}
Lasota-Kuś A. 2018. A cinerary urn from site 21 in Ostrów, Przemyśl District. A contribution to studies on the meaning and role of ornamentation of Early Roman Period ceramic vessels in the Przeworsk culture. Sprawozdania Archeologiczne 70, 153-171.

Early Roman Period pottery of the Przeworsk culture included vessels covered with elaborate zonal decoration. They were particularly typical for sites from the eastern area of this culture. Undoubtedly, at least some of the ornamental motifs, featuring primarily on artefacts from sepulchral contexts, can be seen as a reflection of the spiritual culture of the investigated community. A unique ornamentation has been recorded on a cinerary urn discovered in the Przeworsk culture cemetery at Ostrów, Dist. Przemyśl, site 21. Some of the motifs featuring on the urn find no parallel among symbols known from the period. It cannot be ruled out that they are evidence of contact with Sarmatian tribes, which could have taken place in the upper Dniester basin. The discussed motifs were most likely a form of symbolic message, legible to the community in which they were created.
\end{abstract}

Keywords: Roman Period, Przeworsk culture, ornamentation, symbols

Received: 22.03.2017; Revised: 06.02.2018; Accepted: 14.09.2018

\footnotetext{
* Institute of Archaeology and Ethnology, Polish Academy of Sciences, Sławkowska 17, 31-016 Kraków, Poland; anialasota8o@gmail.com.
} 


\section{INTRODUCTION}

In the Early Roman Period, Przeworsk culture pottery included vessels which stood out from the rest in terms of their shape and decoration. This applies in particular to threehandled vases adorned with elaborate zonal decoration, known primarily from sepulchral sites from the eastern area of the Przeworsk culture. One particular variant of such decoration is the "tri-partite" ornamentation, with different sets of motifs featuring between each pair of handles (Andrzejowski 2001, 80), which typically features on sharply carinated vases. Incidentally, such vessels also occur in the western area of the Przeworsk culture (e.g. Osiek, Dist. Osiek, Wielkopolskie Province, grave 92 - Pawlak 2011, fig. 5: 10).

In this context, it is worth noting vessels with rounded bodies and distinctly separated cylindrical feet, often provided with a small handle, which have incidentally been discovered within the Przeworsk culture range. Some of them are covered with sophisticated decoration. These vessels do not find counterparts in T. Liana's (1970) commonly used typology of Przeworsk culture pottery of the Early Roman Period.

\section{A CINERARY URN FROM OSTRÓW AGAINST THE BACKGROUND OF OTHER VESSELS WITH ROUNDED BODIES AND CYLINDRICAL FEET}

One example of such a vessel is a cinerary urn discovered in grave 84 in the Przeworsk culture cemetery at Ostrów in Przemyśl District (Fig. 1; 2). The necropolis is situated on the left-bank terrace of the broad San River valley, on a slope falling steeply to the southwest. The site lies at the margin of a geographic region known as Foreland Loess Plateau, which is part of the Sandomierz Basin (Kondracki 1994, 239). Excavations carried out in 2013-2014 by Sabina Stempniak and Joanna Motak representing the Arkona archaeological company and Anna Lasota from the Institute of Archaeology of the Jagiellonian University in Kraków resulted in the discovery of around 70 cremation burials linked with the Przeworsk culture, spread over an area of approx. 6 ares. The excavations also allowed the northern, southern, and eastern boundaries of the necropolis to be identified. In the western part of the site the boundary could not be established due to dense development. Preliminary examination of the recovered grave inventories made it possible to determine the time when the cemetery was used as the developed stage of phase B2, until the beginnings of the Younger Roman Period (for more information see: Lasota and Stempniak 2015, 226, 230).

The mentioned urn is a large vessel with a strongly rounded body set on a high foot, and is provided with one perpendicular handle (Fig. 2; 3). The surfaces are carefully polished and blackened, and the paste lacks any macroscopically detectable temper. The rim diameter is $27 \mathrm{~cm}$, maximum body diameter approx. $27.5 \mathrm{~cm}$, and base diameter $11.8 \mathrm{~cm}$. 


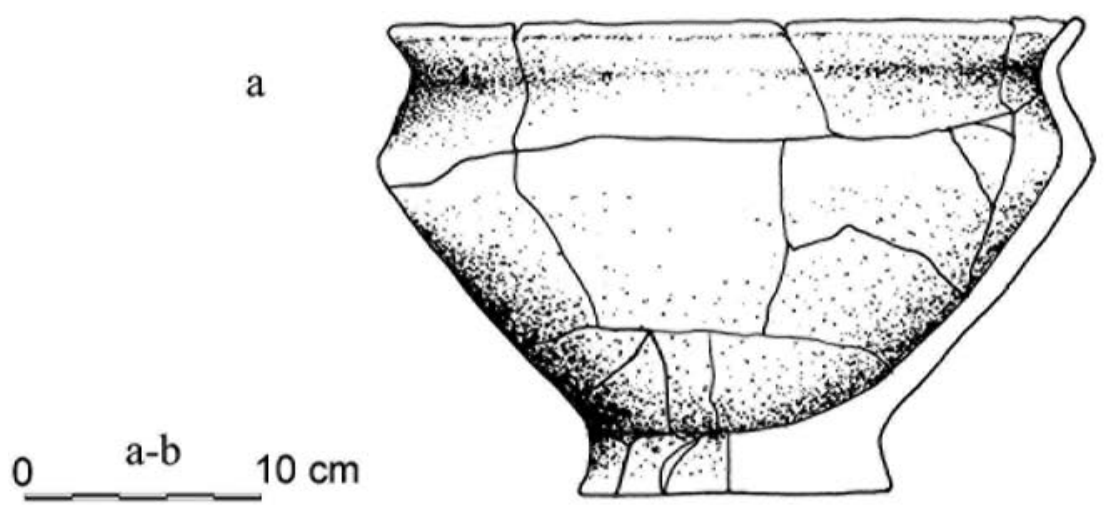

b
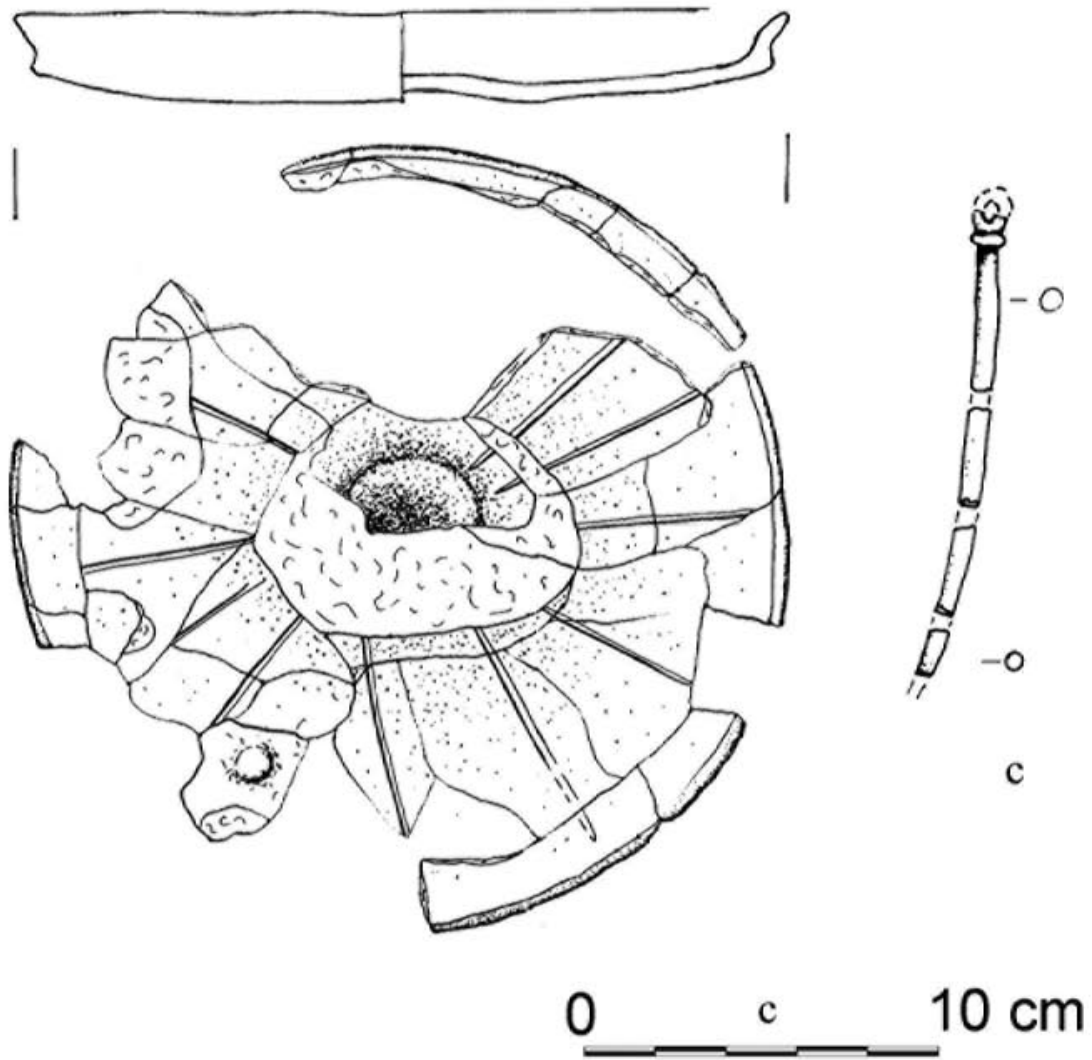

Fig. 1. Inventory of grave 84 from the cemetery in Ostrów, Dist. Przemyśl, site 21: $a-b$ - clay vessels; $c$ - antler pin 

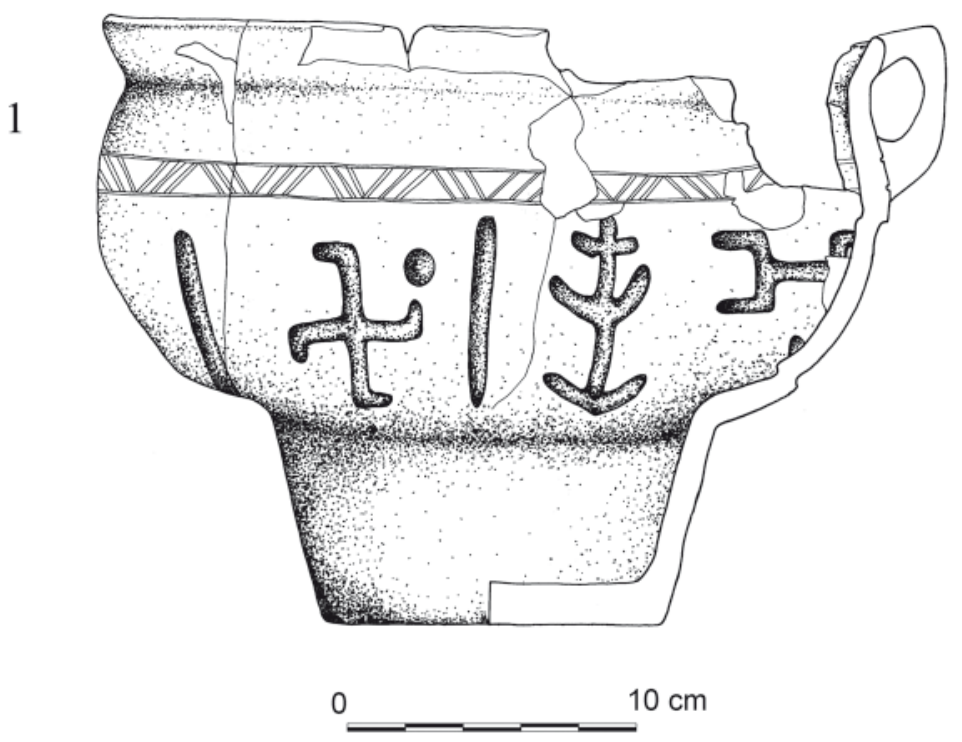

2
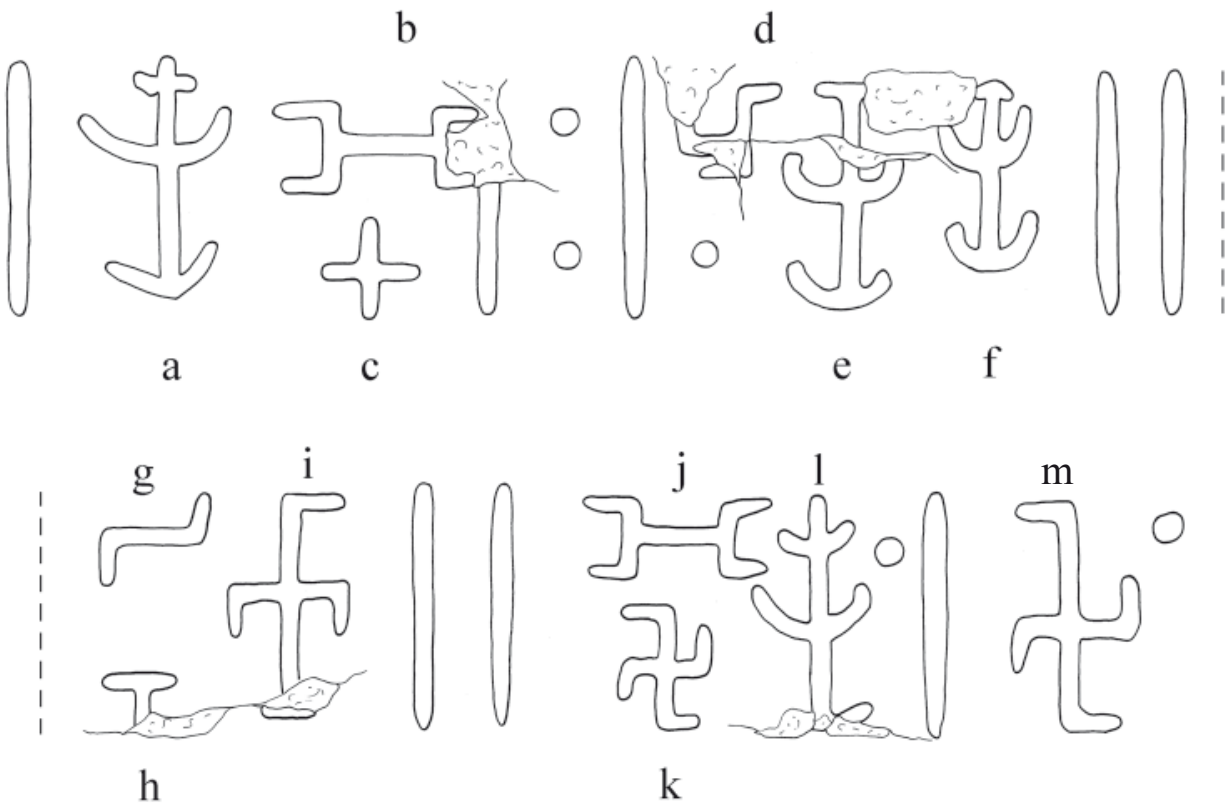

Fig. 2. Cinerary urn from grave 84 from the cemetery in Ostrów, Dist. Przemyśl, site 21: 1 - urn; 2 - a-m ornamentations motifs 

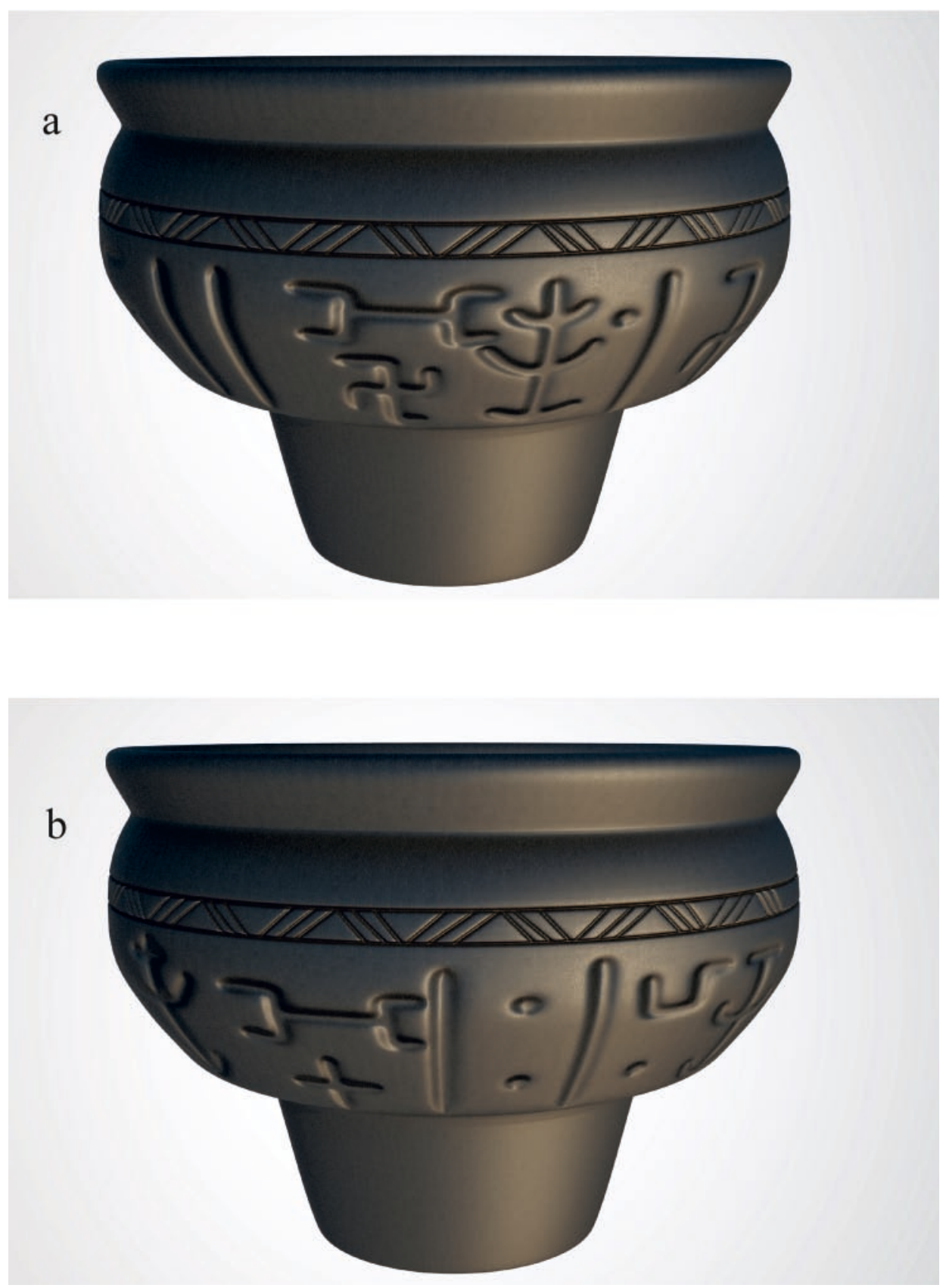

Fig. 3. Reconstruction of the urn from grave 84 from the cemetery in Ostrów, Dist. Przemyśl, site 21: a - swastika, double-fork and tree of life motifs; b - double-fork, cross and vertical flutes motifs 

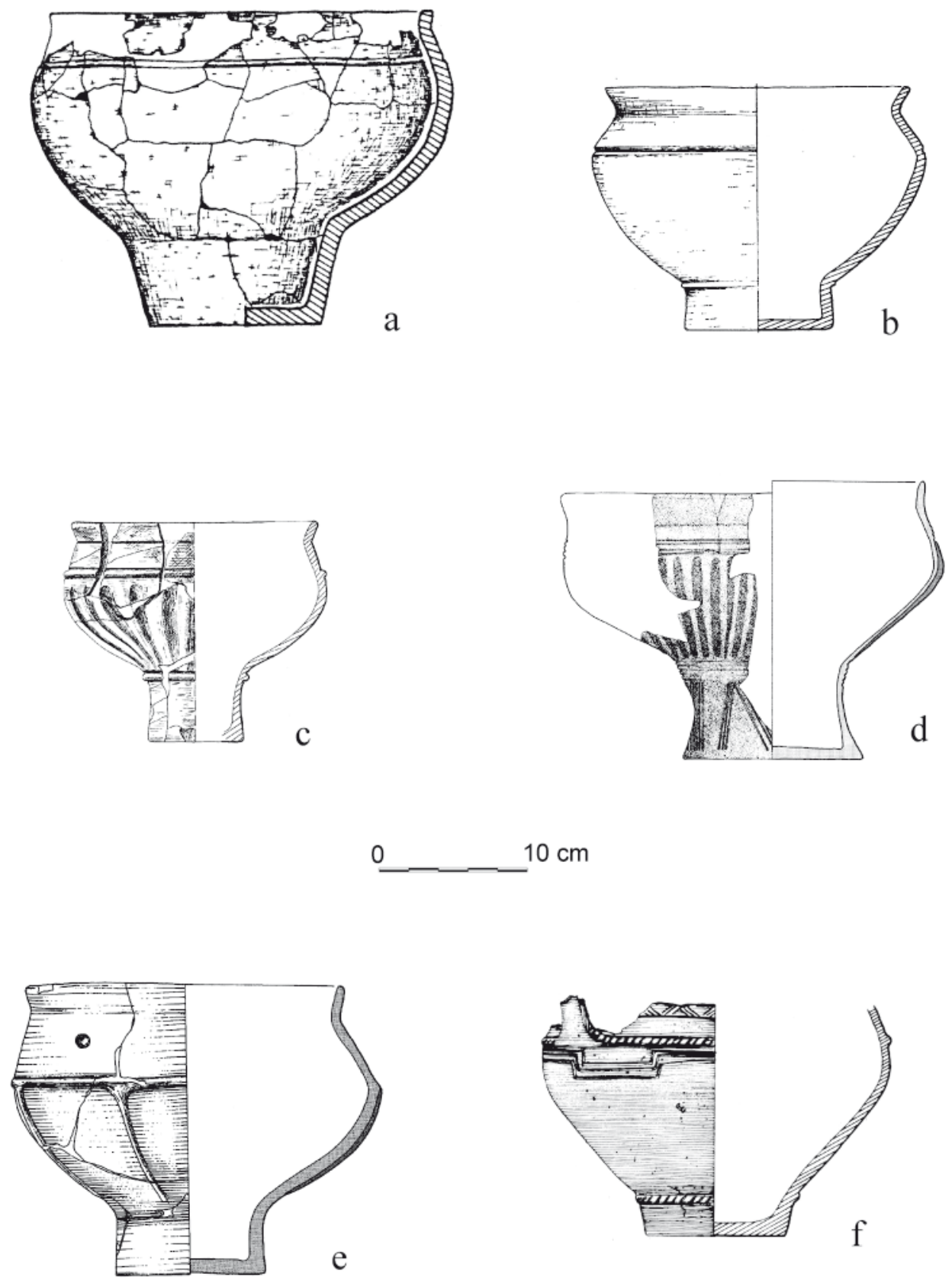

Fig. 4. Vessels with rounded bodies and cylindrical feet: a - Kryspinów, site 2, grave 64; b - Gościeradów, site 1, grave 13; c - Brzeźce, site 2, grave 15; d-Ciebłowice Duże, site 1, grave 12; e - Oblin, site 5, grave 9; f-Kamieńczyk, site 1, grave 199 
The vessel is approx. $21 \mathrm{~cm}$ high, and its cylindrical foot, slightly tapering towards the bottom, has a height of about $7 \mathrm{~cm}$. What attracts particular attention is the decoration covering the vessel's body. It is composed of deeply stamped motifs including swastikas, crosses, hollows, double-fork motifs, and broad, vertical flutes. Grave 84, where the discussed urn was found, was poorly furnished (Fig. 1). All that was found in the grave were burnt-out accompanying vessels and an antler pin with slightly profiled head. The mentioned accompanying vessels included a small bowl of type VI/2, and a vase representing type II/3 in Liana's classification (1970), and another two, highly burnt and typologically undetermined vessels. As for the antler pin, it belongs to Dulkiewicz sub-type VIIC, dated to phases B1 and B2 of the Early Roman Period (Dulkiewicz 2009, 229).

As mentioned at the beginning, vessels of such shape are infrequent finds in Przeworsk culture materials, and the exemplars with elaborate decoration are even less common. The analysis presented below focuses only on the forms with cylindrical feet, while those provided with feet that clearly flare towards the bottom, much more common in Przeworsk culture assemblages, have not been included here.

A similar but undecorated vessel was discovered in the Gać cemetery in the Przeworsk District (Hadaczek 1909, pl. S: 33), a site linked with the eastern area of the Przeworsk culture (cf. Lasota 2014, 152). Unfortunately, specific methods of exploration adopted by the site's discoverer, and the manner of publication, make it impossible to reconstruct the assemblage to which this vessel belonged. The same cemetery also yielded another two forms akin to the vessel discussed here, but having no handles (Hadaczek 1909, pl. M: 5; M: 8). All these artefacts cannot be dated with more precision than within the timespan of the cemetery, which is within phases B2-C1.

In terms of morphology, vessels incidentally discovered in north-eastern Masovia could be parallels to the Ostrów urn. Four such forms have been found in the Kamieńczyk necropolis, site 1, and these are richly adorned (Figs 4: f; 5: a-c). They were accompanied in graves by such metal artefacts as brooches derivative of strongly profiled forms of Dąbrowska variant 5 (grave 78), an A.38 brooch (graves 140 and 199), and an A.149 brooch (grave 231). These artefacts allow the graves to be dated to phase B2b. A similar vessel, also richly ornamented, is known from the Nadkole cemetery, site 2 (Fig. 5: d). It was found in grave 5 dated to phase $2 b$ of the cemetery development, which spanned the closing stages of phase B2a and most of phase B2b (Andrzejowski 1998, 108). Another similar form, although without a handle, is an urn discovered in grave 9 in the Oblin cemetery, site 5. Its decoration is limited to a plastic cordon and two vertical ribs running down from it (Fig. 4: e). A brooch of A.123 type places this assemblage within phase B2 (Czarnecka 2007, 13-14). A vessel from grave 12 in Ciebłowice Duże site 1, in south-western Masovia, is provided with a somewhat different foot, which slightly flares towards the bottom (Fig. 4: d). The grave should be dated to phase B2b, which is indicated by brooches of Almgren group $\mathrm{V}$ series 8 and 10 discovered in this assemblage (Dzięgielewska and Kulczyńska 2008, 14). From western Masovia we have only one vessel referring by its 

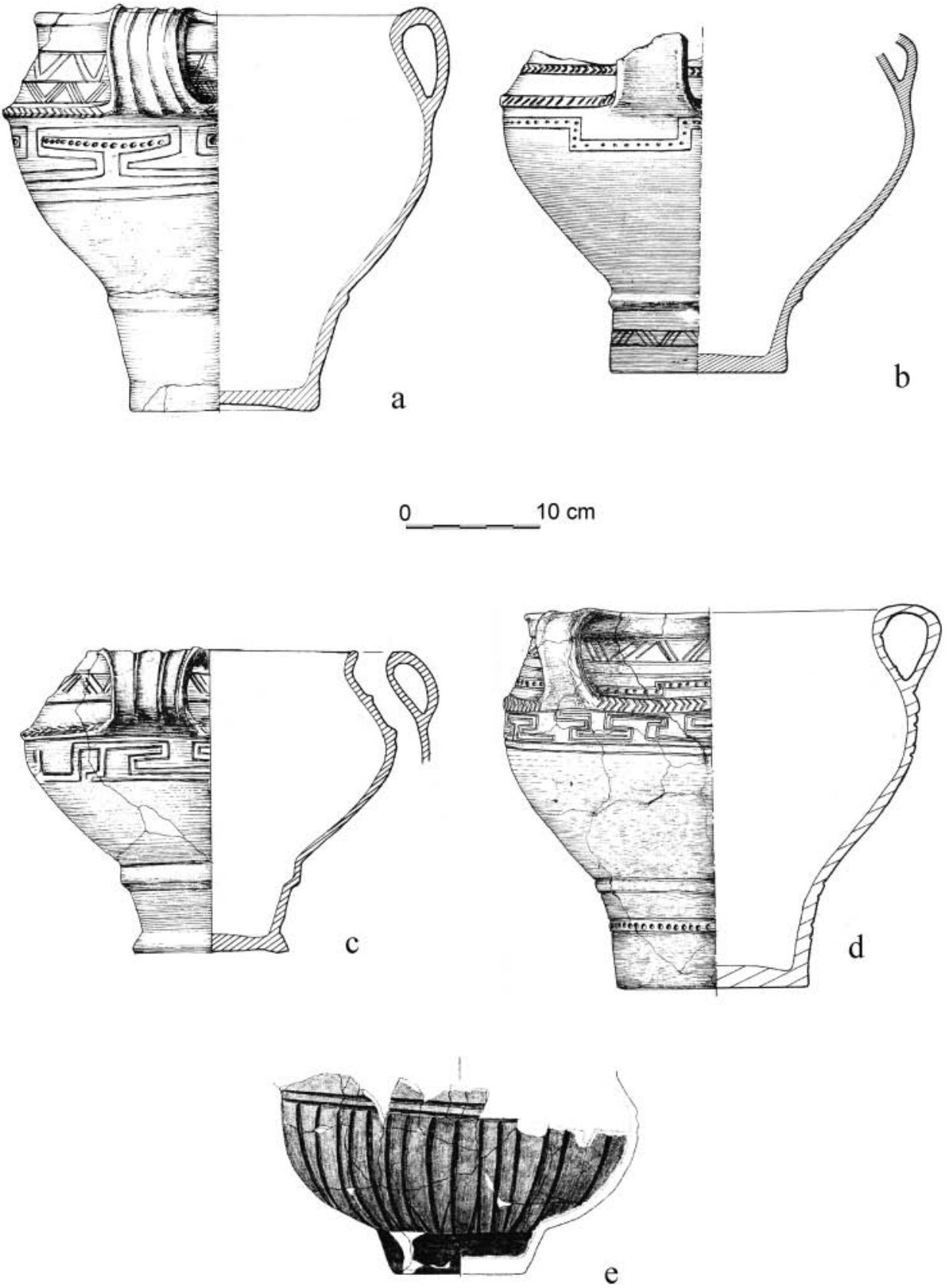

Fig. 5. Vessels with rounded bodies and cylindrical feet: a - Kamieńczyk, site 1, grave 231; b - Kamieńczyk, site 1, grave 78; c - Kamieńczyk, site 1, grave 140; d - Nadkole, site 2, grave 5; e - Sarnia Zwola, site 8, grave 12 
shape to the forms described above. It was found in the Brzeźce cemetery, site 2, in grave 15 (Fig. 4: c) which according to the site's explorer should be dated within phases B2-B2/C1 (Balke 1976, 202; fig. 21: b). It is worth noting that the site also yielded a significant number of vessel bases formed in this characteristic manner (Balke 1976, fig. 19: c, e, pl. IX: 2, 4, 6, 7). However, they may originate from sharply carinated forms. Moreover, all the mentioned cemeteries from the eastern area of the Przeworsk culture produced sharply carinated vases covered with lavish ornamentation, including zonal decoration.

Links to the eastern area of the Przeworsk culture, noticeable in the presence of brooches representing mixed II and IV groups in Almgren classification, and in Kamieńczyk-type bracelets, can be demonstrated for a cemetery in Sarnia Zwola site 8 in Ostrowiec Świętokrzyski District, situated in the Świętokrzyskie Mountains (Orzechowski 2007). Grave 12 yielded a vessel akin to the forms presented above (Fig. 5: e), and the presence of a belt finial of Madyda-Legutko group 1 in the same assemblage allows the grave to be broadly dated to phase B2 (Madyda-Legutko 2011, 33).

In the Lublin region, a similar vessel (but without a handle, as was also the case in Brzeźce) was discovered in grave 13 in the Gościeradów cemetery, Kraśnik District, site 1, on the right bank of the Vistula River (Fig. 4: b). The chronology of the grave is difficult to unambiguously determine, because, apart from the mentioned vessel, it only contained an iron knife and an iron buckle (Niewęgłowski 1981, 78). The latter represents group C type 13 in Madyda-Legutko classification, which is dated within a very broad timespan (MadydaLegutko 1986, 21).

The only vessel of the discussed type known from outside the eastern area of the Przeworsk culture comes from Kryspinów, site 2, from grave 64 (Figs. 4: a; 6). The assemblage also included, among other objects, a bronze trumpet brooch inlaid with silver wire (Godłowski 1974, fig. 2: f) referring to Liana variant 2 (1970, 444), and a fitting from the lock of a wooden box representing type 3 in Kokowski's classification (Kokowski 1997, 38), a relatively rare find in Przeworsk culture sites. The above artefacts date the assemblage to phase B2, probably to its later part.

In other territories within the Przeworsk culture's range one can demonstrate vessel forms which to a certain degree resemble the Ostrów urn. One should mention here one discovered in a cemetery in Wola Łobudzka site 1, in Zduńska Wola District. It has a separated, cylindrical foot, but differs from the vases presented above by its small size and its proportions, which allow the vessel to be classed as a beaker rather than a vase. Moreover, it is decorated with stamped bird motifs and originates from a grave dated within phases C2-C3 (Błaszczyk 1997, 39, pl. III). A vessel discovered in a cemetery in Biała, Zgierz District, is provided with a cylindrical, slightly flaring foot and is decorated with figural motifs, but its body is biconical in shape (Makiewicz 1970, pl. XII: 8-15; XIII: 1).

At the present stage of research, one can conclude that the vessels in question, having rounded bodies and high, cylindrical feet, occurred primarily in the developed stage of phase B2, until the beginnings of the Younger Roman Period. It needs to be emphasized 


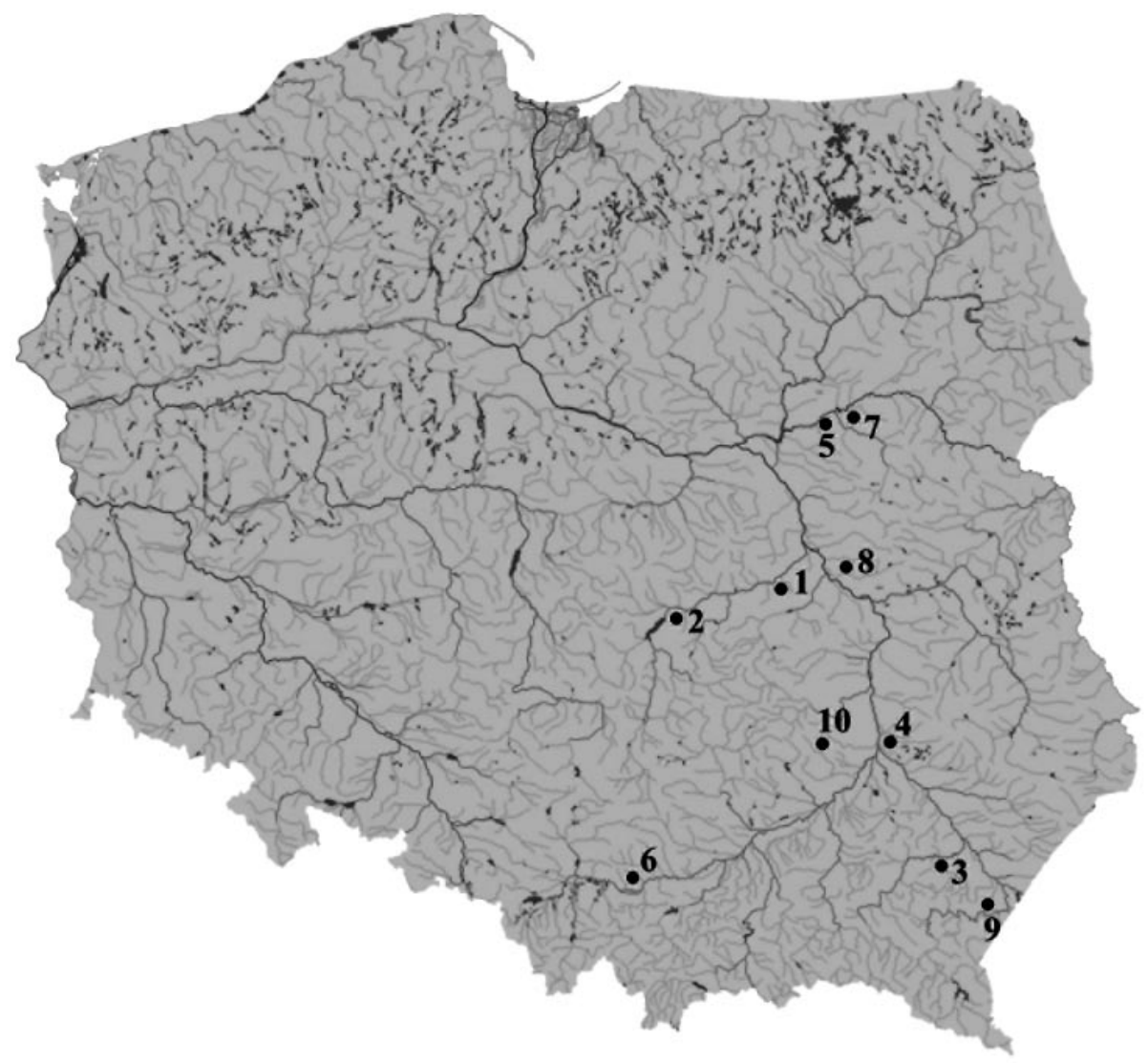

Fig. 6. Distribution of vessels with rounded bodies and cylindrical feet within the Przeworsk culture range: 1 - Brzeźce, site 2, Białobrzegi District (Balke 1976); 2 - Ciebłowice Duże, site 1, Tomaszów Mazowiecki District (Dzięgielewska, Kulczyńska 2007); 3 - Gać, site 1, Przewosk District (Hadaczek 1909); 4 - Gościeradów, site 1, Kraśnik District (Niewęgłowski 1981); 5 - Kamieńczyk, site 1, Wyszków District (Dąbrowska 1997); 6 - Kryspinów, site 2, Kraków District (Godłowski 1974); 7 - Nadkole, site 2, Węgrów District (Andrzejowski 1998); 8 - Oblin, site 5, Garwolin District (Czarnecka 2007); 9 - Ostrów, site 21, Przemyśl District; 10 - Sarnia Zwola, site 5, Ostrowiec Świętokrzyski District (Orzechowski 2007)

that their distribution strongly correlates with the eastern area of the Przeworsk culture (Fig. 6). It is in this area that vessels featuring elaborate narrative decoration (Andrzejowski 1998, 94) and forms adorned with zonal decoration (Dąbrowska 1995, 103; 1996, 113) are also concentrated.

Anthropological analyses performed for eleven graves containing the vessels in question revealed that six vessels held the remains of women. In Ciebłowice Duże, the sex of the deceased buried in grave 12 could not be anthropologically determined, but the nature of the grave goods (metal fittings from a box, a spindle-whorl) suggests it was a woman as 
well. In four other cases the vessels contained bones of adults (men or women) or a child. In light of the above there are no grounds to claim a strict rule reserving a burial in such vessels to people of a particular sex, although a slight predominance of females can be noticed.

\section{FUNCTION OF THE ORNAMENT - ATTEMPT AT INTERPRETATION}

Despite a clear similarity of the vessels described above to the Ostrów urn, one cannot fail to notice that they were not that richly decorated. Their ornamentation most often included incised meander motifs. Vertical flutes were applied in three cases (Ciebłowice Duże, grave 12; Sarnia Zwola, grave 12; Brzeźce, grave 15), and another three were not decorated at all (Gościeradów, grave 13; Gać, Kryspinów, grave 64). As mentioned, the urn from Ostrów stands out with its elaborate decorations. In my opinion, unlike most of the motifs featuring on vessels from settlement sites, which can be considered in terms of "applied arts" (cf. Lis 2001), the decoration executed on the urn in question was not a purely aesthetic treatment but additionally carried certain meanings.

In this context it is worth mentioning a hypothesis formulated by B. Tsetlin, very popular in contemporary Russian archaeology, about the sources of inspiration for creating ornamentation among prehistoric communities. Tsetlin believes that there were three aspects of decoration: magic, biological, and technical. The magic perspective sees the ornamentation as a symbolical transformation of the surrounding world. The biological one suggests that the need for adorning is inspired in humans by the realization of the beauty of the surrounding world. Finally, the decoration created from technical motives was to imitate the technical aspects of the world surrounding prehistoric humans, which found reflection in attempts to render the weave of a fabric, for instance (Tsetlin 2006, 1-2; Koriakova 2006, 14). It cannot be ruled out that to a certain degree all these three factors played a role in inspiring Roman Period people to decorate their vessels.

The ornamentation could have also been a means of signalling identification with a certain social group. This was demonstrated by research into a Hallstatt Period cemetery in Schirdorf in north-east Bavaria. It was observed that vessels featuring certain motifs (festoons and 'lightning bolt' motifs) concentrated in graves situated in different parts of the site and, though representing the same phase of the cemetery, never occurred together in one grave (Brosseder 2006, 125-127). Therefore, it seems justified to assume that certain types of ornamentation were reserved for certain specific groups of graves, probably belonging to people linked by bonds of kinship. Such conclusions, however, cannot be drawn for Ostrów, since the vessel in question is the only one decorated in this manner in the cemetery. Nevertheless, it is worth noticing that the grave where the vessel was discovered was situated close to grave 76 , where a spearhead decorated with motifs probably referring to tamgas was found, among other artefacts. 
As mentioned, in my opinion the motifs featuring on the Ostrów urn may carry some broader, symbolical meaning. As a symbol I understand here a representation linked by an internal relationship with another object, notion, or activity (cf. Kopaliński 1990, 7). Since the culture we are investigating no longer exists, the nature of this link is difficult to precisely determine. Therefore, in the understanding proposed here a symbol should be seen as something not fully determined, the meaning of which was legible only to people from the culture that created it (cf. Kopaliński 1990, 8). Attempts at reading the meaning of symbols featuring on material relics of a given culture must refer to the social structure and the set of ideas available to that society (Hodder 1981, 215-216). In other words, the meaning of a symbol can only be determined on the basis of the context in which it appears (cf. Fromm 2017, 22). By investigating the social sphere, we can also understand the function of ornamentation, since the information encoded in the decoration may refer precisely to this sphere of life of a given society (cf. van den Boom 2000, 188). With respect to prehistoric societies, the above conclusions have been confirmed by ethnographic research, e.g. among contemporary African tribes (Braithwaite 1982).

The sphere of religion, of beliefs, is strongly connected with symbols. Ritual behaviours are full of symbolism, the meaning of which is rooted in the tradition of a society (cf. Minta-Tworzowska 2000, 48). Material relics of ritual behaviours can undoubtedly be found in the highest numbers in sepulchral sites (cf. Bugaj 2013, 65). In Przeworsk culture the relics include ritually damaged vessels and weapons. Some beliefs observed by this population, unclear to us, made them treat the mentioned artefacts in such a manner. Therefore, one should agree that the world of objects, in this case vessels and weapons, is a symbol of the spiritual world (Fromm 2017, 19). Following this line of reasoning, we can arrive at the conclusion that at least some of the ornamental motifs featuring on various artefacts, especially those from cemeteries, are manifestations of the spiritual culture of a given society. This interpretation of the meaning of ornamentation in the Przeworsk culture can be supported by the fact that certain specific motifs are known almost exclusively from cinerary urns (see below).

The analysis of the motifs featuring on the Ostrów urn has led me to a conclusion that they are symbols, codified in a graphic form (cf. Cirlot 2000, 13). The double-fork motif rendered on the urn (Fig. 2: 2b, 2j), which also can be found on other Przeworsk culture vessels from the Early Roman Period, is often interpreted as a human figure in orans posture (Bugaj 1999, 186; Olędzki 2004, 115). However, it should be noted that this interpretation was proposed for a motif arranged "vertically" in relation to other ornamental elements on the vessel, while on the discussed urn it is arranged "horizontally". In this position, it can be assumed to represent a quadruped animal, although what animal exactly is difficult to guess. Figural ornamentation can most often be found on pottery from sepulchral sites, which suggests it was reserved for the sphere of sacrum. However, one should not forget about full relief representations of male heads known from the eastern part of the Jutland Peninsula, which have been found in settlement sites only (Madyda-Legutko 
and Rodzińska-Nowak 2001, 173). Particularly suggestive among figural ornamentations are zoomorphic representations, sometimes quite realistically rendered. In Przeworsk culture materials, zoomorphic relief representations frequently depict quadrupeds or birds, although poor preservation often makes it impossible to determine which category an artefact belongs to (Madyda-Legutko et al. 2000, 212). Animal representations were applied as decorative motifs in the Roman Period, as well as in the Pre-Roman Period and Migration Period (Bantelmann 1981, 227; Bugaj 1999, 180). One of the zoomorphic motifs most frequently occurring in the mentioned periods is the deer. Its realistic depictions feature, among other objects, on two vessels from the cemetery at Gać, Przeworsk District, in Podkarpackie Province (Bugaj and Makiewicz 1995, fig. 7 and unpublished materials). It is also worth mentioning the decoration featuring on an urn discovered in a grave dated to B2-C1a from Costed in North Rhine-Westphalia, a cemetery linked with Rhine-Weser Germanic tribes (Siegmund 1996, pl. 10: 7; 11). The motifs on the urn include a realistically rendered figure of a deer. A detailed analysis of this vessel's decoration published by Reichmann took into account a broad cultural context and drew heavily from Germanic mythology (Reichmann 2005, 389-401). One should keep in mind that the deer is a symbol appearing in many mythologies, and is often associated with a symbol known as the tree of life (cf. Kempiński 1993, 208; Cirlot 2000, 169). Furthermore, according to M. Eliade, in prehistoric beliefs the deer was a fertility symbol, but also was regarded as a funeral animal, a guide for the deceased (Eliade 1994, 100).

At the margin of the above remarks, let us recall that representations known from metal vessels are believed to be the most probable source of inspiration for creating zoomorphic ornamentation on clay vessels (Bantelmann 1981, 228; Bugaj 1999, 169-170). Deer representations also appear on shield brooches, which appeared in Europe as early as the $2^{\text {nd }}-3^{\text {rd }}$ centuries AD, as imports from Roman Provinces (Svoboda 1948, fig. 16; Thomas 1967, 61-62).

The double-fork motif mentioned above can also be found on weapons, the blades of pole weapons in particular (Biborski 1986; P. Kaczanowski 1988). However, it should be noted that on weapons the motif occurs much less frequently than on vessels. The same applies to swastika motifs, which feature on the Ostrów urn three times, both in a clockwise and counter clockwise variant (Fig. 2: 2i, 2k, 2m). Swastika motifs can be demonstrated to have occurred over many centuries, and in the Roman Period they were present in various cultural traditions. The swastika has been given many different interpretations in the literature, the prevailing one being as a solar symbol (Kopaliński 1990, 406-407; Bugaj 1999, 185-186; Cirlot 2000, 390-392). On Early Roman Period vessels, the swastika appears as the only motif, or is part of a larger ornamental composition (e.g. Andrzejowski 1998, pl. X: 1; Dąbrowska 1997, pl. LIX: 5). However, it is worth noticing that it can be found not only on funerary vessels, but also on sherds originating from settlements (e.g. Bolesław, Dist. Dąbrowa, site 1 - Madyda-Legutko 1985, fig. 8: d; Nieszawa Kolonia, Dist. Opole, site 5 - Stasiak-Cyran 2000, fig. 3: d; Piwonice, Dist. Kalisz, site 1 - Dąbrowski 
1955, fig. 7). This means that some of the vessels decorated in that manner may have played certain functions in everyday life, prior to their deposition in grave (cf. Godłowski 1981, 60; Dobrzańska 1990, 63; J. Rodzińska-Nowak 2006, 167). The urn from Gać, Przeworsk District, features what is most likely a different rendering of a solar motif. The symbol has the shape of a round disc surrounded by radiating rays (Bugaj and Makiewicz 1995, fig. 7).

It should be emphasised that the above-mentioned motifs often featuring in the Przeworsk culture on pole weapon blades refer to tamgas, which were owner's marks. They occurred, among other objects, on spearheads from Rozwadów, Dist. Stalowa Wola (Śmiszko 1936, pl. XIX: 2, 5; XX), Zadowice, Dist. Kalisz (Nadolski 1953, fig. 5, 2), and Żurawiczki, Dist. Przeworsk (Kokowski 1994, fig. 3). Such motifs also occur in Sarmatian cultures, a fact well known from the literature (Shchukin 1994, fig. 1; Voroniatov 2012, 186-193). Importantly, from the same milieu we also know swastikas and double-fork motifs (c.f. Yatsenko 2010, fig. 11: 20, 23, 24). On the other hand, these motifs occur in other cultural milieus as well, including in the runic alphabet (Schlette 1972, 196).

The other motifs featuring on the Ostrów urn are unique among ornamentations known from other Przeworsk culture artefacts. Two of them seem to depict human figures in orans posture (Fig. 2: 2e, 2f). The arms and legs point upwards, and the head is marked with a short flute, vertical or arching. One of the alleged figures is slightly bigger than the other. Such a manner of human figure presentation was known in earlier periods as well (c.f. e.g. Müller-Karpe 1968, 52, fig. 29). As mentioned, motifs particularly often interpreted as orans are those described as double-fork. The representation from the base of the vessel from Ciebłowice Duże is a special case, as it additionally features a human head depicted on the axis of the "body" (Dzięgielewska and Kulczyńska 2008, pl. XXXII: 8). Assuming the interpretation of this rather poorly legible drawing is correct (Dzięgielewska and Kulczyńska 2008, pl. CIV: 2), this would be the only such rendering of the double-fork motif on Roman Period pottery. To a certain degree, the interpretation of the motif on the Ostrów urn as a human figure in orans position can be supported by realistic representations of humans with raised arms on pottery in other Roman Period cultures, an urn from the Elbe Germanic cemetery at Hamburg-Marmstorf being a good example (Schwantes 1915, fig. 9; Wegewitz 1964, 26, pl. 10: 6918.1).

Among the remaining motifs appearing on the Ostrów urn there are two which slightly diverge from the orans figures described above, and resemble six-armed trees with emphasised tops (Fig. 2: 2a, 2l). Phitomorphic representations belong to the rarest motifs known from Przeworsk culture materials. Schematically rendered trees accompanied by doublefork motifs interpreted as human figures are known from two vessels from the Wachock necropolis (Balke and Bender 1991, pl. V: 1; VI: 1). The absence of information about the assemblages in which they were found makes their chronology impossible to determine. On the urn from grave 11 in the Opoka cemetery, Puławy District, a schematic representation of a tree is accompanied by a swastika (Stasiak 1994, fig. 12). However, this grave is considerably earlier than the Ostrów burial, as it dates to the close of phase B1 (Stasiak 1994, 63). 
Symbolic meaning can also be assumed with respect to the remaining motifs featuring on the urn in question (Fig. 2: 2c, 2d, 2g, 2h), analogies for which are difficult to find. This may also apply to the hollows featuring near the vertical flute, the swastika, and the motif reminiscent of a tree. Symbolic interpretation has also been proposed for a variety of geometric motifs commonly occurring on cinerary urns from the eastern area of the Przeworsk culture (Dąbrowska 1996, 113). Ethnographic literature offers differing interpretations of geometric patterns. An interesting explanation was recorded by C. Levi-Strauss during his research among indigenous tribes of South America. He was told that the decoration featuring on vessels of the Tupi people, which resembled a lattice of black lines forming a kind of labyrinth, was meant to mislead evil spirits hunting for human bones kept in the urns (Levi-Strauss 1992, 76).

In the context of the interpretations proposed above for the motifs featuring on the urn from the female burial in Ostrów, the tree motif in particular, it is worth recalling a fragment from Tacitus where he wrote that the place where Germanic people performed their rituals was a sacred grove. A branch cut off from a tree was used for fortune-telling (Tacitus, Germania 10). In several other places in Tacitus' accounts we can find information about the high position of female storytellers among Germanic populations. In Book IV of his Histories, Tacitus writes: This maiden [Veleda] of the tribe of the Bructeri enjoyed extensive authority, according to the ancient German custom, which regards many women as endowed with prophetic powers and, as the superstition grows, attributes divinity to them (Tacitus, Histories IV, LXII). In Germania, he emphasised: Further, they conceive that in woman is a certain uncanny and prophetic sense: they neither scorn to consult them, nor slight their answers (Tacitus, Germania, 8).

The motif known as the tree of life has appeared in many cultural milieus (c.f. Kopaliński 1990, 73; Kempiński 1993, 116-117; Cirlot 2000, 114-118), with hints at its Indo-European roots suggested in the literature (Kristiansen and Larsson 2005, 245-246). It enjoyed particular popularity among Sarmatian tribes, including in the first centuries AD. Importantly, in Sarmatian materials the tree of life appeared especially in narrative scenes adorning dress and headband appliques in rich female burials. The motif was usually accompanied there by representations of animals, including birds and deer, which were shown approaching the tree of life (e.g. Zasetskaia 2011, 72). Graves furnished with such artefacts have been interpreted as burials of priestesses (Istvánovits and Kulcsár 2011, 215-216). Furthermore, representations of trees rendered in a manner similar to that on the Ostrów urn appear on Geto-Dacian relief vessels between the $2^{\text {nd }}$ century BC and the $1^{\text {st }}$ century AD. The vessels also feature animal representations, probably deer, as well as female figures performing 'ritual dance' (Sîrbu and Florea 2011, fig. 2: 1-3). It cannot be ruled out that the inspiration for such decoration may have been drawn from the Sarmatian milieu (Sîrbu and Florea 2011, 315-316). 


\section{RECAPITULATION}

To sum up, it should be emphasized that this paper does not pretend to be a comprehensive analysis of the phenomenon in question. Instead, it offers an attempt at interpretation of the meaning of some of the symbols known from Przeworsk culture pottery. The motifs featuring on the Ostrów urn have been interpreted here as symbols carrying broader meaning and being most likely associated with the sphere of beliefs of the investigated population. As known from the literature, this sphere of human life ranks among those most difficult to interpret through its material remains (Baron 2009, 420). At the same time, I am aware that there are more than few scholars for whom the presence of symbols in chronologically distant cultures remains an open question (cf. Kowalski 1999, 7, 173).

It cannot be unambiguously claimed that the symbols depicted on the Ostrów urn are evidence of Sarmatian influences on the beliefs, and therefore also symbolism, of the Przeworsk culture. Contacts between these two groups, which undoubtedly took place on the upper Dniester, have been widely addressed in the literature (e.g. Shchukin 994, 489-490; Kokowski 1999; Dobrzańska 2001, 102). However, one cannot rule out a possibility that the analysed ornamental motifs emerged independently, as a one-time inspiration of the vessel's creator. This is indirectly suggested by the lack of close analogies for some of the motifs. The latter probably were a form of symbolic message legible to its receivers at the time.

The brief outline of possible interpretations of some drawings featuring on Przeworsk culture vessels presented above obviously does not exhaust the issue. Attempts at reading the messages encoded in symbols are always a difficult task. Furthermore, studies into symbolism and religion of past societies investigated by archaeologists require particular caution and distance, and should always be set in a broad cultural context.

\section{Acknowledgements}

I would like to express my deep gratitude to Dr hab. Anita Szczepanek from the Institute of Archaeology and Ethnology of the Polish Academy of Sciences, Kraków, who performed the anthropological examination of cremated bones from grave 84 from the Ostrów cemetery.

\section{References}

Andrzejowski J. 1998. Nadkole 2. A cemetery of the Przeworsk Culture in Eastern Poland (= Monumenta Archaeologica Barbarica 5). Kraków: Instytut Archeologii i Etnologii Polskiej Akademii Nauk, Państwowe Muzeum Archeologiczne w Warszawie.

Andrzejowski J. 2001. Wschodnia strefa kultury przeworskiej - próba definicji. Wiadomości Archeologiczne 54 (1995-1998), 59-87.

Balke B. 1976. Cmentarzysko z okresu rzymskiego w Brzeźcach, pow. Białobrzegi (stanowisko 2). Wiadomości Archeologiczne 41, 155-209. 
Balke B. and Bender W. 1991. Cmentarzysko kultury przeworskiej w Wąchocku, woj. kieleckie. Studium krytyczne materiałów. Materiały Starożytne i Wczesnośredniowieczne 6, 121-190.

Bantelmann H. 1981. Figural verzierte Gefäße aus Süderbrarup, Kreis Schleswig-Flensburg. Offa 38, 219-229.

Baron J. 2009. Badania nad religią pradziejową w polskiej archeologii. Sprawozdania Archeologiczne 61, 419-436.

Biborski M. 1986. Zdobiona broń z cmentarzyska ciałopalnego z okresu wpływów rzymskich z Gaci k. Przeworska. Materiaty Archeologiczne 23, 113-134.

Błaszczyk J. 1997. Naczynie z wyobrażeniami ptaków z Woli Łobudzkiej, stan. 1, gmina Szadek. Acta Universitatis Lodziensis. Folia Archaeologica 21, 31-42.

Boom H. van den 200o. Ceramika jako nośnik znaczenia: rozważania nad zdobnictwem ceramiki. In B. Gediga and D. Piotrowska (eds.), Kultura symboliczna kręgu pól popielnicowych epoki brąu i wczesnej epoki żelaza $w$ Europie środkowej. Warszawa, Wrocław, Biskupin: Państwowe Muzeum Archeologiczne w Warszawie, Instytut Archeologii i Etnologii Polskiej Akademii Nauk, 183-199.

Braithwaite M. 1982. Decoration as ritual symbol: a theoretical proposal and an ethnographic study in southern Sudan. In I. Hodder (ed.), Symbolic and structural archaeology. London, New York, New Rochelle, Melbourne, Sydney: Cambridge University Press, 80-88.

Brosseder U. 2006. Eben sozialer Identitäten im Spiegel des Zeichensystems hallstattzeitlicher Keramik. In M. K. H. Eggert and U. Veit (eds.), Soziale Gruppen - Kulturelle Grenzen. Die Interpretation sozialer Identitäten in der Prähistorischen Archäologie. New York, München, Berlin: Waxmann, 119-138.

Bugaj E. 1999. Motywy figuralne na ceramice germańskiego kręgu kulturowego. Poznań: Wydawnictwo Naukowe UAM.

Bugaj E. 2013. O metodach narracji obrazowej na przykładzie wybranych przedstawień na greckiej ceramice geometrycznej. In J. Kolendo, A. Mierzwiński, S. Moździoch and L. Żygadło (eds.), Z badań nad kultura spoleczeństw pradziejowych i wczesnośredniowiecznych. Księga jubileuszowa dedykowana Profesorowi Bogusławowi Gedidze w osiemdziesiąta rocznice urodzin przez przyjaciót, kolegów i uczniów. Wrocław: Instytut Archeologii i Etnologii Polskiej Akademii Nauk, 61-79.

Bugaj E. and Makiewicz T. 1995. Ornamentyka figuralna na naczyniach glinianych okresu przedrzymskiego i rzymskiego w Polsce. Przegląd Archeologiczny 43, 87-122.

Cirlot J. E. 2000. Stownik symboli. Kraków: Wydawnictwo Znak.

Czarnecka K. 2007. Oblin. Ein Gräberfeld der Przeworsk-Kultur in Südmasowien (= Monumenta Archaeologica Barbarica 13). Warszawa: Państwowe Muzeum Archeologiczne w Warszawie.

Dąbrowska T. 1995. Dwie bogato zdobione popielnice z cmentarzyska kultury przeworskiej w Kamieńczyku, woj. ostrołęckie. In A. Bursche, M. Mielczarek and W. Nowakowski (eds.), Nunc de Svebis dicendum est. Studia archeologica et historica Georgii Kolendo ab amici et discipuli dicata. Studia dedykowane profesorowi Jerzemu Kolendo w 6o-lecie urodzin i 4o-lecie pracy naukowej. Warszawa: Instytut Archeologii UW, 103-110. 
Dąbrowska T. 1996. Uwagi o ornamentyce ceramiki przeworskiej z wczesnego okresu wpływów rzymskich. Studia Gothica 1, 111-120.

Dąbrowska T. 1997. Kamieńczyk. Ein Graberfeld der Przeworsk-Kultur in Ostmasowien (= Monumenta Archaeologica Barbarica 3). Kraków: Instytut Archeologii i Etnologii Polskiej Akademii Nauk - Państwowe Muzeum Archeologiczne w Warszawie.

Dąbrowski K. 1955. Badania archeologiczne we wsi Piwonice w pow. kaliskim w roku 1954. Sprawozdania Archeologiczne 1, 49-59.

Dobrzańska H. 1990. Osada z późnego okresu rzymskiego w Igołomi, woj. krakowskie. Część 2. Wrocław, Kraków: Zakład Narodowy im. Ossolińskich.

Dobrzańska H. 2001. Contacts between Sarmatians and the Przeworsk Culture community. In E. Istvánovits and V. Kulcsár (eds.), International Connections of the Barbarians of the Carpathian Basin in the $1^{\text {st }}-5^{\text {th }}$ centuries A. D. Aszód, Nyíregyháza: Osváth Gedeon Museum Foundation, Jósa András Museum, 101-115.

Dulkiewicz A. 2009. Szpile kościane i rogowe kultury przeworskiej na terenie Polski: typologia, chronologia i rozmieszczenie. Folia Praehistorica Posnaniensia 15, 209-235.

Dzięgielewska M. and Kulczyńska M. 2008. Ciebłowice Duże. Ein Gräberfeld der Przeworsk-Kultur im südwestlichen Masowien (= Monumenta Archaeologica Barbarica 5). Warszawa: Fundacja Monumenta Archaeologica Barbarica, Państwowe Muzeum Archeologiczne w Warszawie.

Eliade M. 1994. Historia wierzeń i idei religijnych II. Od Gautamy Buddy do początków chrześcijaństwa. Warszawa: Instytut Wydawniczy PAX.

Fromm E. 2017. Zapomniany język. Wstęp do rozumienia snów, baśni i mitów. Kraków: vis-a-vis/ etiuda.

Godłowski K. 1974. Kryspinów, district of Kracow (A cemetery of the Late La Tène and the Roman periods). Recherches Archeologiques de 1973, 27-35.

Godłowski K. 1981. Kultura przeworska. In J. Wielowiejski (ed.), Prahistoria Ziem Polskich 5. Późny okres lateński i okres rzymski. Wrocław, Warszawa, Kraków, Gdańsk: Zakład Narodowy im. Ossolińskich, Wydawnictwo Polskiej Akademii Nauk, 57-135.

Hadaczek K. 1909. Cmentarzysko ciałopalne koło Przeworska (z epoki cesarstwa rzymskiego) (= Teka Konserwatorska 3/2). Lwów: Grono C. K. Konserwatorów.

Hodder I. 1981. Pottery, production and use: a theoretical discussion. In H. Howard and E. L Morris (eds.), Production and Distribution: a Ceramic Viewpoint (= British Archaeological Research. International Series 120). Oxford: Archaeopress, 215-220.

Istvánovits E. and Kulcsár V. 2011. Satana and Others: Priestesses, Witches and Queens of the SteppeRegion. In D. Quast (ed.), Weibliche Eliten in der Frühgeschichte. Internationale Tagung vom 13. Bis zum 14. Juni 2008 im RGZM im Rahmen des Forschungsschwerpunktes „Eliten“. Mainz: Schnell \& Steiner, 201-218.

Kaczanowski P. 1988. Chronologia inkrustowanych grotów broni drzewcowej z okresu wpływów rzymskich z obszarów europejskiego Barbaricum. In M. Gedl (ed.), Scripta Archaeologica. Kraków: Uniwersytet Jagielloński, 51-77. 
Kempiński A. M. 1993. Stownik mitologii ludów indoeuropejskich. Poznań: Wydawnictwo SAWW.

Kokowski A. 1994. Problemy badania dziejów kultury przeworskiej. Kultura Przeworska 1. Lublin: Wydawnictwo Uniwersytetu Marii Curie-Skłodowskiej, 15-36.

Kokowski A. 1997. Die Schlossbeschläge und die Schüssel aus dem nördlichen Barbaricum in der römischen Kaiserzeit und frühen Völkerwanderungszeit. Klasyfikacja zabytków archeologicznych 2. Lublin: Wydawnictwo Uniwersytetu Marii Curie-Skłodowskiej.

Kokowski A. 1999. Strefy kulturowe w młodszym okresie przedrzymskim i w okresie rzymskim na łuku Karpat. Część I - od młodszego okresu przedrzymskiego do młodszego okresu rzymskiego. In S. Czopek and A. Kokowski (eds.), Na granicach antycznego świata. Sytuacja kulturowa $w$ potudniowo-wschodniej Polsce i regionach sqsiednich $w$ mlodszym okresie przedrzymskim i okresie rzymskim. Rzeszów: Muzeum Okręgowe, 25-44.

Kondracki J. 1994. Geografia Polski. Mezoregiony fizyczno-geograficzne. Warszawa: Państwowe Wydawnictwo Naukowe.

Kopaliński W. 1990. Stownik symboli. Warszawa: Wiedza Powszechna.

Koriakova L. 2006. Some approaches to ceramic study. In D. Gheorgiu (ed.), Ceramic Studies: Papers on the social and cultural significance of ceramics in Europe and Eurasia from prehistoric to historic times (= British Archaeological Research. International Series 1553). Oxford: Archaeopress, 11-17.

Kowalski A. P. 1999. Symbol w kulturze archaicznej. Poznań: Wydawnictwo Naukowe Instytutu Filozofii.

Kristiansen K. and Larsson T. 2005. The Rise of Bronze Age Society. Cambridge: Cambridge University Press.

Lasota A. 2014. Grób wojownika z cmentarzyska w Gaci, pow. przeworski. Przyczynek do studiów nad lokalnymi formami okuć tarczy w kulturze przeworskiej. In R. Madyda-Legutko and J. Rodzińska-Nowak (eds.), Honoratissimum assensus genus est armis laudare. Studia dedykowane Profesorowi Piotrowi Kaczanowskiemu z okazji siedemdziesiątej rocznicy urodzin. Kraków: Historia Jagiellonica, Towarzystwo Wydawnicze, 151-16o.

Lasota A. and Stempniak S. 2015. Nowo odkryte cmentarzysko z wczesnego i młodszego okresu wpływów rzymskich w Ostrowie, stan. 21, gm. Przemyśl, woj. podkarpackie. In L. Tyszler and E. Droberjar (eds.) Barbari superiores et inferiores. Archeologia barbarzyńców. Łódź, Wieluń: Instytut Archeologii Uniwersytetu Łódzkiego, Muzeum Ziemi wieluńskiej w Wieluniu, Stowarzyszenie Naukowe Archeologów Polskich Oddział w Łodzi, 225-233.

Lévi-Strauss C. 1992. Smutek tropików. Łódź: Wydawnictwo Opus.

Liana T. 1970. Chronologia względna kultury przeworskiej we wczesnym okresie rzymskim. Wiadomości Archeologiczne 35, 429-491.

Lis V. 2001. Ceramika kultury łużyckiej jako przejaw sztuki użytkowej. Wybrane przykłady. In B. Gediga, A. Mierzwiński and W. Piotrowski (eds.), Sztuka epoki brq̨zu i wczesnej epoki żelaza w Europie Środkowej. Wrocław, Biskupin: Polska Akademia Nauk O/Wrocław, Muzeum Archeologiczne w Biskupinie, 201-212. 
Madyda-Legutko R. 1985. Wyniki badań przeprowadzonych na osadzie kultury przeworskiej w Bolesławiu, woj. tarnowskie. In S. Potępa (ed.), Tarnoviana. Tarnów: Muzeum Okręgowe w Tarnowie, 181-203.

Madyda-Legutko R. 1986. Gürtelschnallen der römischen Kaiserzeit und der frühen Völkerwanderungszeit im mitteleuropäischen Barbaricum (= British Archaeological Research. International Series 360). Oxford: Archaeopress.

Madyda-Legutko R. 2011. Studia nad zróżnicowaniem metalowych części pasów w kulturze przeworskiej. Okucia końca pasa. Kraków: Instytut Archeologii Uniwersytetu Jagiellońskiego.

Madyda-Legutko R. and Rodzińska-Nowak J. 2001. (reviev): Ewa Bugaj, Motywy figuralne na ceramice germańskiego kręgu kulturowego. Archeologia Polski 46, 169-173.

Madyda-Legutko R., Rodzińska-Nowak J. and Zagórska-Telega J. 200o. Unikatowe naczynie z cmentarzyska w Opatowie, woj. śląskie, stan. 1. Uwagi na temat plastyki zoomorficznej występującej na ceramice kultury przeworskiej w okresie rzymskim. In J. Rydzewski (ed.), 15 o lat Muzeum Archeologicznego w Krakowie. Kraków: Muzeum Archeologiczne w Krakowie, 209-220.

Makiewicz T. 1970. Cmentarzysko z okresu rzymskiego w Białej, pow. Łódź. Prace i Materiały Muzeum Archeologicznego i Etnograficznego $w$ Lodzi. Seria Archeologiczna 17, 175-255.

Minta-Tworzowska D. 2000. Symbole i symbolika z perspektywy badań archeologicznych. In B. Gediga and D. Piotrowska (eds.), Kultura symboliczna kręgu pól popielnicowych epoki brąu i wczesnej epoki żelaza w Europie środkowej. Warszawa, Wrocław, Biskupin: Państwowe Muzeum Archeologiczne w Warszawie, Instytut Archeologii i Etnologii Polskiej Akademii Nauk, 45-54.

Müller-Karpe H. 1968. Das vorgeschichtliche Europa, Kunst der Welt. Baden-Baden: Holle Verlag.

Nadolski A. 1953. Dwa interesujące przedmioty z cmentarzyska w Zadowicach, pow. Kalisz. Sprawozdania P.M.A. 5, 90-92.

Niewęgłowski A. 1981. Cmentarzysko kultury przeworskiej z okresu rzymskiego w Gościeradowie, gm. loco, woj. Tarnobrzeg. Sprawozdania Archeologiczne 33, 61-98.

Olędzki M. 2004. Uwagi na temat znaczenia ornamentu symbolicznego umieszczonego na naczyniu odkrytym w Niechmirowie-Małej Wsi (grób 684). In M. Olędzki and J. Skowron (eds.), Kultura przeworska. Odkrycia - Interpretacje - Hipotezy 1. Łódź: Uniwersytet Łódzki, Wydział Studiów Międzynarodowych i Politologicznych, Katedra Badań Wschodu, 115-119.

Orzechowski S. 2007. Zaplecze osadnicze i podstawy surowcowe starożytnego hutnictwa świętokrzyskiego. Kielce: Kieleckie Towarzystwo Naukowe.

Pawlak E. 2011. Cmentarzysko ludności kultury przeworskiej w Osieku koło Jarocina. Wstępne wyniki badań. Wielkopolskie Sprawozdania Archeologiczne 12, 295-315.

Reichmann Ch. 2005. Die Bildurne von Costed. In H.-J. Häßler (ed.), Neue Forschungsergebnisse zur nordwesteuropäischen Frühgeschichte unter besonderer Berücksichtigung der altsächsischen Kultur im heutigen Niedersachsen (= Studien zur Sachsenforschung 15). Berlin: Oldenburg: Isensee, 389-401.

Rodzińska-Nowak J. 2006. Jakuszowice stanowisko 2. Ceramika z osady kultury przeworskiej z mtodszego i późnego okresu wphywów rzymskich i wczesnej fazy okresu wędrówek ludów (= Prace Archeologiczne 61). Kraków: Uniwersytet Jagielloński. 
Schlette F. 1972. Germanen zwischen Thorsberg und Ravenna. Leipzig, Jena, Berlin: Urania Verlag.

Schwantes G. 1915. Zur Entwicklungsgeschichte der Mäanderurnen des Elbgebietes. Praehistorische Zeitschrift 7, 45-67.

Shchukin M. 1994. Shields, swords and spears as evidence of Germanic-Sarmatian contacts and Barbarian-Roman relations. In C. von Carnap-Bornheim (ed.), Beiträge zu römischer und barbarischer Bewaffnung in den ersten vier nachchristlichen Jahrhunderten. Lublin, Marburg: Philips-Universität, 485-495.

Siegmund F. 1996. Das Gräberfeld der jüngeren Kaiserzeit von Costedt. Münster: Verlag Phillip von Zabern in Wissenschaftliche Buchgesellschaft.

Sîrbu V. and Florea G. 2011. Geto-Dacian pottery vessels (2nd century BC-1st century AD): Imitation and originality. In E. Papuci-Władyka, M. Vickers, J. Bodzek and D. Braund (eds.), Pontika 2008, Recent Research on the Northen and Eastern Black Sea in Ancient Times (= British Archaeological Research. International Series 2240). Oxford: Archaeopress, 311-318

Stasiak M. 1994. Ceramika z cmentarzyska kultury przeworskiej w Opoce (= Kultura Przeworska 2). Lublin: Wydawnictwo Uniwersytetu Marii Curie-Skłodowskiej.

Stasiak-Cyran M. 200o. Wyniki piątego sezonu badań na osadzie kultury przeworskiej w NieszawieKolonii, stanowisko 5, pow. Opole Lubelskie. Archeologia Polski Środkowowschodniej 5, 85-95.

Svoboda B. 1948. Čechy a ř́mské Imperium. Sborník Národního muzea v Praze. Ǩada A - Historie (= Acta Musei Nationalis Pragae. Series A - Historia 2). Praha: Národní muzeum, 1-253.

Śmiszko M. 1936. Grot dzirytu z runicznym napisem z Rozwadowa nad Sanem. Wiadomości Archeologiczne 14, 140-145.

Tacitus C. P. 1914. Germania, translated by W. Peterson. London: Willam Heinemann Ltd, New York: The Macmillan CO.

Tacitus C. P. 1962. Histories, translated by C. H. Moore. Cambridge: Harvard University Press - London: Willam Heinemann Ltd.

Thomas S. 1967. Die germanischen Scheibenfibeln der römischen Kaiserzeit im freien Germanien. Berliner Jahrbuch für Vor- und Frühgeschichte 7, 4-187.

Tsetlin Y. B. 2006. The Origin of Graphic Modes of Pottery Decoration. In A. Gibson (ed.), Prehistoric Pottery: Some Recent Research (= British Archaeological Research. International Series 1509). Oxford: Archaeopress, 1-10.

Voroniatov S. 2012. Sarmatische Elemente im Inventar des Königsgrabs von Mušov in Südmähren. Eurasia Antiqua, Zeitschrift für Archäologie Eurasiens 18, 185-195.

Wegewitz W. 1964. Der Urnenfriedhof von Hamburg-Marmstorf (= Die Urnenfriedhöfe in Niedersachsen 7). Hildesheim: A. Lax.

Yatsenko S. A. 2010. Marks of the Ancient and Early Medieval Iranian-Speaking Peoples of Iran, Eastern Europe, Transoxiana and South Siberia. In J. E. Pim, A. Yatsenko and O. T. Perrin (eds.), Traditional Marking Systems. London, Dover: Dunkling Books, 133-154.

Zasetskaia I. P. 2011. Sokrovishcha Kurgana Khokhlach. Novocherkasskii klad. Sankt-Peterburg: Izd-vo Gos. Ermitazha. 
